\title{
Platelet ice attachment to instrument strings beneath the Amery Ice Shelf, East Antarctica
}

\author{
M. CRAVEN, ${ }^{1,2}$ R.C. WARNER, ${ }^{1,2}$ B.K. GALTON-FENZI, ${ }^{1,2}$ \\ L. HERRAIZ-BORREGUERO, ${ }^{2}$ S.W. VOGEL, ${ }^{1,2}$ I. ALLISON ${ }^{2}$ \\ ${ }^{1}$ Australian Antarctic Division, Kingston, Tasmania, Australia \\ E-mail: Roland.Warner@aad.gov.au \\ ${ }^{2}$ Antarctic Climate and Ecosystems Cooperative Research Centre (ACE CRC), University of Tasmania, Hobart, Tasmania, \\ Australia
}

\begin{abstract}
Oceanographic instruments suspended beneath the Amery Ice Shelf, East Antarctica, have recorded sporadic pressure decreases of 10-20 dbar over a few days at three sites where basal marine ice growth is expected. We attribute these events to flotation due to platelet ice accretion on the instrument moorings. Some events were transient, rapidly returning to pre-event pressures, probably through dislodgement of loosely attached crystals. Driven by these pressure changes, temperatures recorded by the shallowest instruments (within $20 \mathrm{~m}$ of the shelf base) tracked in situ freezing temperatures during the events. These observations provide indirect evidence for the presence of frazil ice in the sub-ice-shelf mixed layer and for active marine ice accretion. At one site we infer that a dense layer of platelet ice $\sim 1.5 \mathrm{~m}$ thick was accreted to the ice shelf over a 50 day period. Following some permanent abrupt pressure decreases (which we interpret as due to the lodgement of the uppermost instrument at the ice-shelf base), altered background trends in pressure suggest compaction rates of 3-4 $\mathrm{m} \mathrm{a}^{-1}$ for the accreted basal platelet layer. Attachment of platelet ice and resulting displacement of moorings has ramifications for project design and instrument deployment, and implications for interpretation of oceanographic data from sub-ice-shelf environments.
\end{abstract}

KEYWORDS: glaciological instruments and methods, ice shelves, ice/ocean interactions

\section{INTRODUCTION}

Ice shelves play an important role in the mass budget of Antarctic ice. Much of the ice flowing from the continent reaches the Southern Ocean through these floating extensions of the grounded ice sheet. Ice shelves lose ice in approximately equal proportions by basal melting through interaction with the sub-ice-shelf ocean and by the calving of icebergs (Depoorter and others, 2013; Rignot and others, 2013). At the calving front the stresses within the flowing ice shelf are balanced against the pressure of the ocean, but stresses in ice shelves also transmit retarding forces from sidewalls and pinning points which reduce ice flow rates at the grounding line (Thomas and MacAyeal, 1982; Dupont and Alley, 2005; Gudmundsson, 2013). This buttressing effect of ice shelves is thought to have a strong control on the discharge of ice from the grounded ice sheet and hence on ice-sheet mass budget and eustatic sea level (Rott and others, 2002; Rignot and others, 2004; Scambos and others, 2004).

High rates of basal melting occur near the deep grounding lines of ice shelves and floating glacier tongues. The apparent sensitivity of these basal melting rates to ocean temperature and sub-ice-shelf circulation makes the ocean/ ice-shelf system an important coupling between the Antarctic ice sheet and the rest of the global climate system (Rignot and Jacobs, 2002; Shepherd and others, 2004; Pritchard and others, 2012). Melting of ice at depth beneath ice shelves drives a thermohaline circulation in the sub-ice cavity that can also lead to the deposition of marine ice at the ice-shelf base at shallower drafts via the 'ice pump' mechanism (Foldvik and Kvinge, 1974; Lewis and Perkin, 1986; Jacobs and others, 1992). In some regions of the Ronne (Lambrecht and others, 2007) and Amery (Fricker and others, 2001) ice shelves, the marine ice layer constitutes a substantial proportion of the total ice-shelf column. The role of marine ice in ice-shelf stability and sensitivity to climate change is of considerable interest for understanding the long-term evolution of ice shelves (Lange and MacAyeal, 1986; Hulbe and others, 2005).

The sub-ice-shelf environment is difficult to access, and only sparse observations of basal ice/ocean interactions are available. Between 2001 and 2010 the Amery Ice Shelf Ocean Research (AMISOR) project (Craven and others, 2004) established a network of six hot-water drilled boreholes through the Amery Ice Shelf (Fig. 1). As well as exploring the internal structure of the ice shelf (Craven and others, 2005, 2009; Treverrow and others, 2010), oceanographic moorings were deployed beneath each borehole, gathering detailed temperature, pressure and salinity records from the sub-ice-shelf ocean cavity to gain insight into iceshelf/ocean interaction processes (Leffanue and Craven, 2004; Breitenmoser, 2008).

In this paper, we focus on some unexpected events from the AMISOR pressure records that provide insights into ocean processes near the base of the ice shelf. We report sporadic rapid 10-20 dbar pressure changes from CTD (conductivity, temperature, depth) instruments fixed on moorings beneath the ice shelf at three sites where a substantial marine ice layer (150-210 m thick) is present. Together with temperature and salinity data from the moorings, these events shed light on ice/ocean interaction processes and provide insights into the formation and transport of frazil ice in the water column, which (as well as accreting to moorings) can attach and grow as platelets at the base of the ice shelf to create a marine ice layer. 


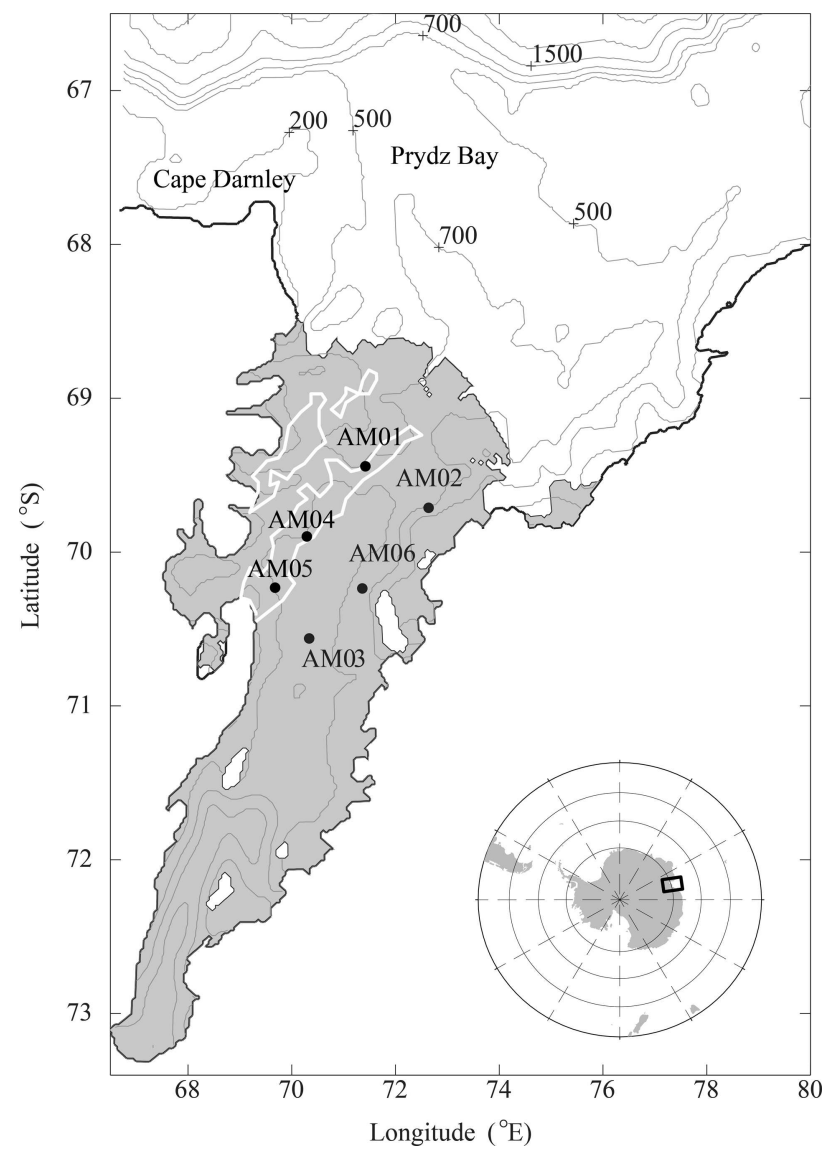

Fig. 1. The Amery Ice Shelf (grey area) with borehole site locations and bathymetry contours in front of the shelf depicted by thin grey curves (from Galton-Fenzi and others, 2008). Boreholes AM01, AM04 and AM05 are along an ice flowline within the marine ice band $(150 \mathrm{~m}$ thick marine ice contour shown by thick white lines, from Fricker and others, 2001). Inset: location of the Amery Ice Shelf in East Antarctica.

\section{ICE FORMATION IN SUPERCOOLED SEA WATER}

There is some ambiguity in the literature concerning terminology for ice in the sub-ice-shelf environment. Frazil ice, or simply frazil, refers to ice crystals that grow in water and are transported in suspension. The term 'platelet ice' has been adopted by the majority of authors discussing marine ice within ice shelves. Tison and others (1998) considered the issue of textural facies vs generic processes as a means of discriminating between various ice types, and attributed platelet ice formation as being due to unrestrained frazil ice nucleation and growth arising from the adiabatic supercooling of sea water. In this paper, we refer to frazil if the ice is in suspension and to platelet ice if the ice is attached to either the bottom of the ice shelf or to objects such as our moorings. When citing the literature we retain the terminology of the original authors.

Frazil is known to form in proximity to ice shelves and floating ice tongues as part of the ice pump circulation, in which sea water, having melted ice at depth and consequently been cooled and freshened, becomes supercooled as it ascends to shallower drafts (Foldvik and Kvinge, 1974; Lewis and Perkin, 1986; Jacobs and others, 1992; Penrose and others, 1994). Substantial layers of marine ice can form at the ice/sea-water interface through accretion of frazil and consolidation as platelets over time (Morgan, 1972; Thyssen,
1988; Oerter and others, 1992; Fricker and others, 2001; Lambrecht and others, 2007). The platelet structure of the deep marine ice layer at the base of the Amery Ice Shelf has been observed by video camera at two locations, AM01 and AM04 (Fig. 1) (Craven and others, 2005, 2009). An unconsolidated slush layer has been described the base of the Ronne Ice Shelf (Nicholls and Jenkins, 1993). Also, a 'mushy layer', penetrated by tubular brine conduits increasing in number with depth making it highly permeable near the base, has been reported for the Roi Baudouin ice shelf (Hubbard and others, 2012). Platelet ice has also been reported either as disc-shaped crystals (Lange, 1988) or as large vertical crystals $5 \mathrm{~mm}$ thick and $20 \mathrm{~mm}$ long observed at the bottom of a core through $416 \mathrm{~m}$ of ice from the Ross Ice Shelf, the lower $6 \mathrm{~m}$ of which was marine ice (Zotikov and others, 1980).

Platelet ice has also been found attached to instrument strings deployed in the ocean. Leonard and others (2006) reported events from McMurdo Sound where ice crystals of various sizes attached to instrument cables formed a cylinder $30 \mathrm{~cm}$ in diameter and up to $25 \mathrm{~m}$ in length. Ice appeared on the cable during periods of supercooling in the ocean beneath the fast ice cover (Leonard and others, 2011; Gough and others, 2012). This platelet ice appeared during winter, but with a high degree of interannual variability (Smith and others, 2001). Other studies have also reported platelet ice growth on instruments to depths of $50 \mathrm{~m}$ (Wright and Priestley, 1922; Barry, 1988), occasionally providing sufficient buoyancy to lift an instrumented mooring array by several metres (Hunt and others, 2003; Mahoney and others, 2011). Recently Tyler and others (2013) suggested that ice accretion on a lightly weighted optical fibre mooring under the McMurdo Ice Shelf potentially enhanced currentinduced mooring swings rising $>150 \mathrm{~m}$.

\section{EXPERIMENTAL SET-UP}

Since 2001 the AMISOR project has been investigating ice/ ocean interaction processes in the cavity beneath the Amery Ice Shelf. The cavity was accessed between 2001 and 2010 via six hot-water drilled boreholes through which instrumented moorings were established (Fig. 1). Three of the six sites (AM01, 479 m ice thickness; AM04, 603 m; and AM05, $624 \mathrm{~m}$ ) are located along a flowband (Fig. 1) where a layer of accreted marine ice exceeding $200 \mathrm{~m}$ thickness forms the base of the ice shelf (Fricker and others, 2001; Craven and others, 2009). The other three sites (AM02, 373 m; AM03, $722 \mathrm{~m}$; and AM06, $607 \mathrm{~m}$ ) are situated toward the eastern side of the ice shelf, in areas believed to be dominated by basal melting.

Each mooring (Table 1) carries three fixed Seabird SBE37-IM MicroCAT CTD units, which are suspended below the ice-shelf base. Each MicroCAT consists of a cylinder $62 \mathrm{~mm}$ in diameter and $526 \mathrm{~mm}$ in length, with a perforated sensor guard along approximately half that length, which increases the transverse extent to $103 \mathrm{~mm}$. Weights attached to the ends of the moorings apply tension to the cables. The upper CTD (top) was generally suspended $\sim 20 \mathrm{~m}$ below the ice/water interface, another (middle) in the middle of the water column, and the lower (bottom) unit generally $\sim 40 \mathrm{~m}$ above the seabed. The deepest CTD at AM04 was $>100 \mathrm{~m}$ above the seabed because of a shortage of mooring cable. Table 1 also indicates the periods for which CTD data are available. 
Table 1. Ice-shelf thickness, marine ice thickness, water column thickness and depths of instruments at mooring sites AM01-AM06. CTD positions are given as depths beneath the base of the ice shelf

\begin{tabular}{|c|c|c|c|c|c|c|}
\hline & AM01 & AM02 & AM03 & AM04 & AM05 & AM06 \\
\hline Total ice thickness (m) & 479 & 373 & 722 & 603 & 624 & 607 \\
\hline Marine ice thickness (m) & 203 & 0 & 0 & 208 & $>140^{\dagger}$ & 0 \\
\hline Water column thickness $(\mathrm{m})$ & 362 & 468 & 617 & 399 & 355 & 295 \\
\hline Deployment date & Jan 2002 & Jan 2001 & Dec 2005 & Jan 2006 & Dec 2009 & Jan 2010 \\
\hline Top CTD* $(m)$ & 20 & 12 & 20 & 17 & 21 & 18 \\
\hline Bottom CTD* (m) & 320 & 444 & 580 & 277 & 314 & 253 \\
\hline \multirow[t]{2}{*}{ Operational period } & Jan 2002 & Jan 2001 & Dec 2005 & Jan 2006 & Dec 2009 & Jan 2010 \\
\hline & Jan 2009 & Jan 2006 & July 2011 & Dec 2010 & Ongoing & Ongoing \\
\hline
\end{tabular}

*Distance below the base of the ice shelf at the time of deployment.

${ }^{\dagger}$ The marine ice thickness was not directly measured at AM05 (but later inferred to be $>140 \mathrm{~m}$ from fibre-optic temperature data).

\section{DATA QUALITY}

The conductivity, temperature and pressure data recorded by the CTDs provide readings every $30 \mathrm{~min}$. Data have been collected annually via an inductive modem link during summertime site visits. Manufacturer-supplied calibrations were applied to all CTDs prior to deployment (Table 1 for deployment dates). Data downloads are checked manually, with obvious errors flagged and reported. No drift corrections are applied to the data. This is because we lack postdeployment calibrations since the sub-ice-shelf installations are permanent. Pressure is reported here in decibars 1 dbar $=10 \mathrm{kPa}$ ) because in sea water a $1 \mathrm{dbar}$ pressure difference can be regarded as corresponding to a $1 \mathrm{~m}$ depth interval. Several instrument failures impacted upon the continuity of the datasets acquired; in particular, pressure transducers failed on the moorings at AM01 (middle and lower) and AM05 (upper).

A lack of drift correction in the measured quantities has different implications for the various data types reported here. For the pressure we will focus on changes in pressure, measured over relatively short time intervals (days to weeks). Manufacturer-specified drift rates are $0.004 \%$ of full-scale range per month. Our instruments are rated to $1000 \mathrm{~m}$ (top and middle sensors) or $2000 \mathrm{~m}$ (bottom sensor), which implies an upper drift limit of $0.08 \mathrm{dbar}_{\text {month }}{ }^{-1}$. Since we restrict pressure difference values to the nearest $0.5 \mathrm{dbar}$, the lack of any drift correction is negligible. For the temperature we need to be able to detect departures from in situ freezing point temperatures by as little as $0.01^{\circ} \mathrm{C}$ as an indication of supercooling in the water column (Lewis and Perkin, 1986). Instrument accuracy is quoted as $0.002^{\circ} \mathrm{C}$, with manufacturer-specified drift rates of $0.0002^{\circ} \mathrm{C}$ month $^{-1}$. Supercooling at this level can therefore be reliably determined up to 5 years beyond deployment, which coincides with the practical lifetime of the units due to expiry of the internal battery (Table 1). An estimation of error due to drift needs to be kept in mind, however, when temperature data are discussed. Salinity is calculated from all three measured values (conductivity, temperature and pressure), with associated errors dominated by the accuracy and precision of the conductivity cell. We will not directly discuss salinity data here, although it enters into calculations of the in situ sea-water freezing temperature. The freezing temperatures are pressure- and salinity-dependent and are calculated using the CTD observations in the TEOS-10 subroutines from the Gibbs Seawater (GSW) Oceanographic Toolbox (McDougall and Barker, 2011).

\section{OBSERVATIONS}

Sporadic rapid pressure changes of $\sim 10-20 \mathrm{dbar}$ are prominent features at the three sites along the marine ice band: AM05, AM04 and AM01 (Fig. 1). The fixed CTD units deployed on each mooring recorded these pressure changes synchronously (Table 2). No pressure jumps of this nature were recorded at any of the three moorings on the eastern, marine-ice-free portion of the ice shelf (AM06, AM03 and AM02). We discuss each of the sites along the marine ice band in turn, starting with AM04, where complete pressure records are available from all three instruments on the mooring, and the progression of events is most clearly evident.

Table 2. Pressure decreases exceeding a threshold magnitude of $10 \mathrm{dbar}$ recorded at the three marine ice band borehole sites (AM01, AM02 and AM05). The transition time indicates the number of days it took for the pressure change to reach a maximum. The duration shows how long the mooring stayed at the new pressure level for the transient events. The second sustained event at AM04 in 2010 at DoY 227 was recorded by the lower CTD units only

\begin{tabular}{lcccc}
\hline $\begin{array}{l}\text { Borehole site } \\
\text { (year of event) }\end{array}$ & $\begin{array}{c}\text { Pressure } \\
\text { change } \\
\text { dbar }\end{array}$ & $\begin{array}{c}\text { Timing DoY } \\
\text { (month) }\end{array}$ & $\begin{array}{c}\text { Transition } \\
\text { time }\end{array}$ & Duration \\
& & & days & days \\
\hline AM01 (2002) & -13.5 & 34 (Feb) & 9 & 9 \\
AM01 (2002) & -18.5 & 117 (Apr) & 1 & 1 \\
AM01 (2002) & -12.0 & 158 (Jun) & 1 & 1 \\
AM01 (2003) & -19.0 & 95 (Apr) & 4 & 15 \\
AM01 (2003) & -18.5 & 117 (Apr) & 2 & 10 \\
AM01 (2003) & -17.5 & 145 (May) & $4^{*}$ & - \\
AM04 (2008) & -15.5 & 178 (Jun) & 2 & 12 \\
AM04 (2009) & -16.0 & 190 (Jul) & $3^{*}$ & - \\
AM04 (2010) & $-14.0(-23.0)^{\dagger}$ & 227 (Aug) & $43^{*}$ & - \\
AM05 (2011) & -15.5 & 218 (Aug) & $<5^{*}$ & - \\
AM05 (2011) & -10.5 & 290 (Oct) & 3 & 3 \\
& & & & \\
\hline
\end{tabular}

*Sustained pressure change event. ${ }^{\dagger}$ Peak transient pressure changes. 

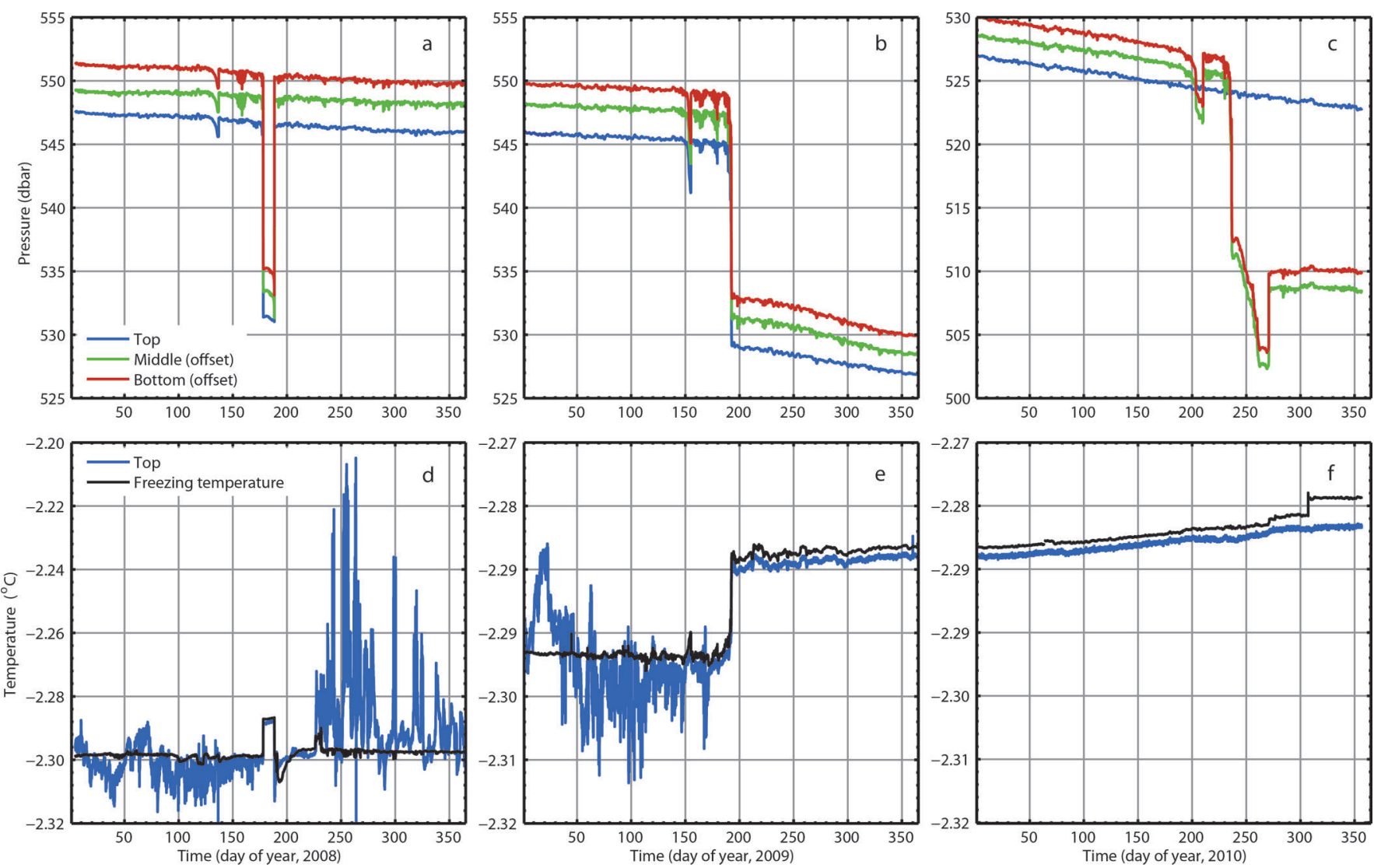

Fig. 2. AM04 pressure $(\mathrm{a}-\mathrm{c})$ and in situ temperature $(\mathrm{d}-\mathrm{f})$ time series for 2008, 2009 and 2010. The calculated in situ sea-water freezing temperatures for the top CTD are also shown (black curves). Pressure records for the middle and lowest CTDs are offset to permit comparison.

\section{AMO4}

For the first 2 years after deployment (2006 and 2007) the most prominent feature of the pressure $(P)$ record from the AM04 mooring is a slow background decrease with time. This is due chiefly to strain thinning of the ice shelf as it flows seaward, overlain with additional smaller contributions from surface accumulation ( $P$ increase), basal freezing ( $P$ decrease) and fluctuations from changes in atmospheric pressure. From 2008 onwards, rapid synchronous pressure 'jumps' were observed, superimposed on the background pressure trend (Fig. 2a-c). In 2008, all three instruments synchronously recorded transient decreases in pressure of equal magnitude (15.5 dbar), at day of year (DoY) 178 (June) (Fig. 2a; Table 2). This persisted for $\sim 12$ days before returning abruptly (between half-hourly recordings) to pre-event pressures. In 2009, all three instruments again recorded small transient decreases in pressure after DoY 150 (May), followed by a larger rapid and permanent $16.0 \mathrm{dbar}$ decrease around DoY 190 (July) (Fig. 2b; Table 2). There was also a significantly faster decline in the background pressure after this sustained event. With all three CTDs on the mooring simultaneously recording features of the same magnitude and character, it is evident they are real and not artefacts of faulty transducers.

In 2010, abrupt pressure decreases were recorded by the two deeper sensors (Fig. 2c). A small transient pressure decrease after DoY 200 (July) was followed by a rapid, sustained pressure decrease of $14.0 \mathrm{dbar}$ at DoY 227 (August). This major pressure change was preceded by small oscillatory signals, and followed by a prolonged further decrease of 9.0 dbar over 34 days, much of which was abruptly recovered at DoY 270 (October). This sequence of abrupt events was not recorded by the upper sensor, which simply continued with the steady decreasing background trend throughout 2010. In contrast, no background trend was observed for the two deeper pressure sensors after the abrupt rise in pressure at DoY 270.

The upper CTD, initially deployed in the ocean mixed layer within $20 \mathrm{~m}$ of the ice-shelf base, provides insight into the temperature regime of the conditions that exist there. In each of the first three years of deployment (2006-08) this CTD recorded temperatures at or below the in situ freezing temperature of sea water from the beginning of the year until around the start of the austral spring (September), with some interannual variability, when a sudden switch to a warmer state with larger fluctuations occurred. These temperatures reduced over time until a return to freezing-point conditions was re-established by the end of the year (austral summer) as seen in Figure $2 \mathrm{~d}$ for 2008 . However, the temperature record for 2008 also displayed a temperature response to the abrupt pressure event around DoY 178 (June), which closely followed the calculated in situ freezing-point temperature (Fig. 2d). A similar temperature response was seen during the permanent pressure decrease in 2009 (Fig. 2e). No such temperature variations were observed from the upper CTD during the pressure changes observed during 2010 (Fig. 2f).

Also significant is the decrease in temperature variability associated with these pressure events, which is most pronounced following the permanent pressure drop in 2009. The difference between observed temperature and calculated freezing temperature visible in the remainder of the record may be due to calibration or drift (in each of the sensors), or may actually indicate some level of super- 

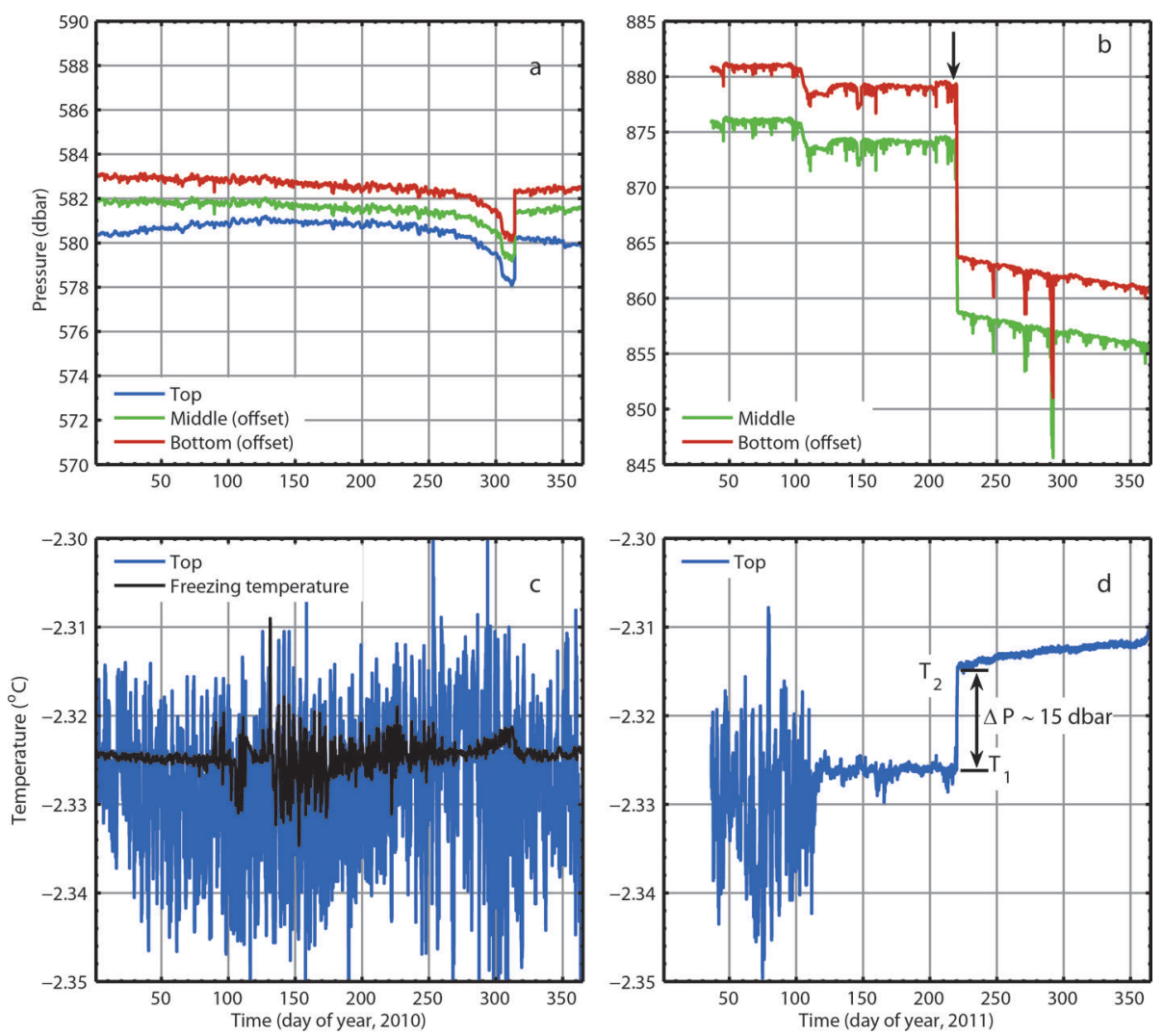

Fig. 3. AM05 pressure (a, b) and in situ temperature (c, d) time series for $2010(a, c)$ and 2011 (b, d). An anomalous 10 dbar steady decrease has been detrended from the top CTD. This unit failed in early 2011. Pressure records have been offset to permit comparison. The calculated in situ sea-water freezing temperatures for the top CTD are also shown (black curves). (d) shows the calculated change in in situ freezingpoint temperature expected for a $15 \mathrm{dbar}$ pressure drop.

cooling. As well as the decrease in temperature variability after the 2009 event, there is a more subtle decrease in variability preceding it. Similar decreases in variability are observed during and after the transient 2008 event. An abrupt change in the calculated in situ freezing temperature in late 2010 (Fig. 2f) is due to a sudden decrease in the measured salinity. This may have a purely technical explanation (e.g. low battery voltage) or an environmental explanation (e.g. ice crystal interference within the conductivity cell). No data are available beyond the end of 2010 as the CTD units became unresponsive. We presume the batteries had been exhausted.

\section{AM05}

In December 2009, instrumentation was installed at AM05, $\sim 45 \mathrm{~km}$ upstream of AM04, along the same ice-shelf flowband in the marine ice zone. During 2010 the pressure sensor in the upper instrument recorded a strong decreasing trend of $>10 \mathrm{dbar}$ for the year, regarded as unreliable (removed by linear regression in Fig. 3a), and certainly incompatible with the lower sensors, which recorded more believable changes of $\sim 1$ dbar. AM05 is in a region of converging ice flow, and by analysis of the MEASURES (Making Earth Science Data Records for Use in Research Environments) compilation of satellite-derived ice velocities (Rignot and others, 2011) we conclude that the vertical strain rate in the region around AM05 is small, possibly slightly positive, so that strain-thinning effects on pressure measurements there should be small. Unfortunately, the pressure sensor in the upper instrument failed immediately following the annual 2010/11 summer data download and provided no further data. However, the middle and lower pressure sensors recorded a $15.5 \mathrm{dbar}$ synchronized sharp decrease in early August 2011, DoY 218 (Fig. 3b; Table 2).

Temperatures from the upper sensor at AM05 remained close to (often below) the in situ freezing-point temperature throughout 2010 (Fig. 3c). In 2011, the temperature sensor recorded $\mathrm{a} \sim 0.01^{\circ} \mathrm{C}$ increase synchronously with the August (DoY 218) pressure jumps in the deeper instruments (Fig. 3b and d). Earlier in 2011, a smaller (2-3 dbar) drop in pressure around DoY 100 (April) was accompanied by significant persistent reduction in temperature variability recorded by the upper CTD unit.

Following the permanent August 2011 (DoY 218) event, the pressure records from the two deep CTD units remained highly synchronized for the remainder of the year (Fig. 3b). A series of transient pressure falls of increasing amplitude peak at $10.5 \mathrm{dbar}$ around DoY 290. The record from the upper CTD temperature sensor (Fig. 3d) contains no responses corresponding to these transient pressure changes, although the gradual increase in temperature following the major sustained pressure decrease (DoY 218) is broadly consistent with the increase of in situ freezing temperature that would be expected given the background trend of decreasing pressures seen in the two deep CTDs (Fig. 3b).

\section{AM01}

Located $68 \mathrm{~km}$ downstream of AM04 along the same iceshelf flowband, the AM01 borehole mooring was deployed in January 2002. This was the first mooring to be installed under the marine ice band. Pressure data from the mooring were initially assessed as unreliable, but after analysis of the 

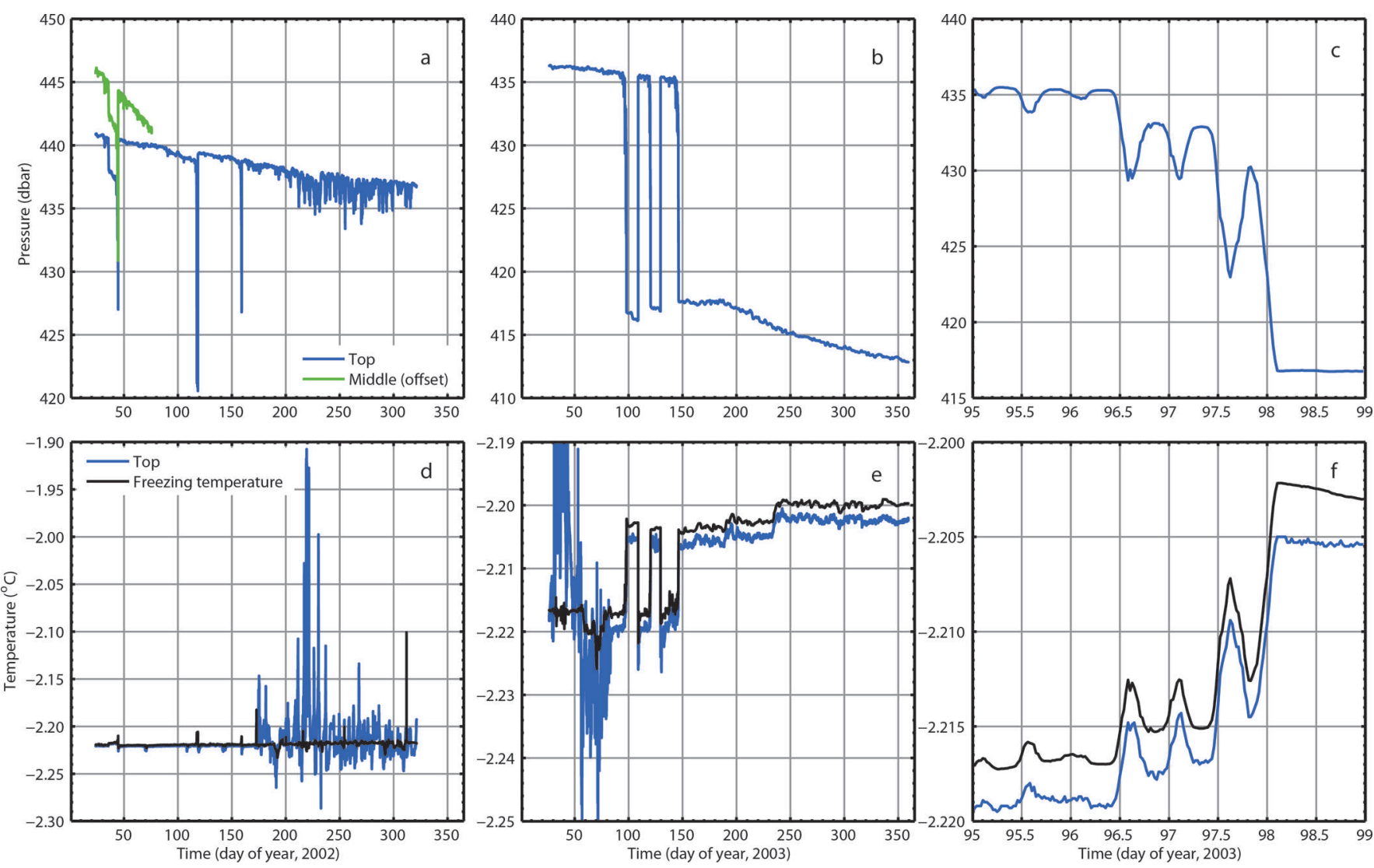

Fig. 4. (a, b, d, e) AM01 upper CTD pressure $(a, b)$ and in situ temperature (d, e) time series for $2002(\mathrm{a}, \mathrm{d})$ and 2003 (b, e). (c, f) Detailed plots for pressure (c) and temperature (f) for DoY 95-99 for 2003. The calculated in situ sea-water freezing temperatures for the top CTD are also shown (black curves). A fragment of pressure data from the middle CTD is shown (green curve) in (a), offset for comparison.

AM04 and AM05 records they were revisited, and records of similar abrupt pressure events were found.

Pressure sensors in the two deeper CTDs recorded strong decreasing trends immediately after deployment, similar to the situation with the upper sensor at AM05, but then failed completely after the first few months of operation. Nevertheless, superimposed on this trend was an initial small (2-3 dbar) abrupt pressure drop at the middle CTD at AM01 starting around DoY 34 (February), leading into a short-lived further 10 dbar spike, which was also recorded synchronously by the upper CTD pressure transducer (Fig. 4a; Table 2). The pressure record for 2002 from the upper sensor was characterized mainly by a series of significant, sharp, short-lived drops: $13.5 \mathrm{dbar}$ around DoY 34 (February), $18.5 \mathrm{dbar}$ around DoY 117 (April), and finally $12.0 \mathrm{dbar}$ around DoY 158 (June).

During 2003 the pressure jumps in the remaining CTD (Fig. 4b; Table 2) were longer-lasting: 10-12 days each for the $19.0 \mathrm{dbar}$ event starting DoY 95 (April), and the $18.5 \mathrm{dbar}$ event starting DoY 117 (April), before a permanent drop of $17.5 \mathrm{dbar}$ was recorded starting around DoY 145 (May). From around DoY 190 (July) 2003, the upper pressure transducer began to record a more rapid decreasing trend of $\sim 4-5 \mathrm{dbar} \mathrm{a}^{-1}$ (Fig. 4b) with no further abrupt changes, either transient or permanent. A detailed record of the first major pressure jump of 2003 (DoY 95-98) is shown in Figure 4c.

As at the other two sites, the major pressure events at AM01 were accompanied by coincident temperature changes recorded by the upper sensor (Fig. 4e and f) that are well correlated with in situ freezing temperature changes calculated from the pressure and salinity records. The observed temperature record continued to track the in situ freezing temperature closely, following the last permanent decrease in pressure. The variation of the calculated in situ freezing temperature after DoY 200 (Fig. 4e) is dominated by changes in measured salinity (not shown).

\section{DISCUSSION: ORIGIN OF THE PRESSURE JUMPS}

Our observations show that individual abrupt pressure events occur simultaneously on all operational instruments at a given mooring, with the same change in pressure at each depth. This suggests that a vertical displacement of the mooring (with respect to local sea level) is taking place, resulting in an equal change of depth for all instruments on the mooring.

A variety of processes and events can influence pressures measured by moorings suspended beneath a floating ice shelf, over a range of amplitudes and timescales. There is a direct response to atmospheric pressure; ocean currents can push the mooring sideways, lifting it as a damped pendulum; changes in ice-shelf thickness due to the flow deformation and mass loading of the ice shelf can alter the depth of the suspended mooring; changes in buoyancy of the mooring can cause it to rise or fall; or combinations of these mechanisms can occur. We review each of these possibilities briefly to determine the likely origin of the abrupt pressure variations observed in our mooring data.

\section{Atmospheric pressure changes}

The CTD pressure transducers respond directly to atmospheric pressure changes. Atmospheric variations at 

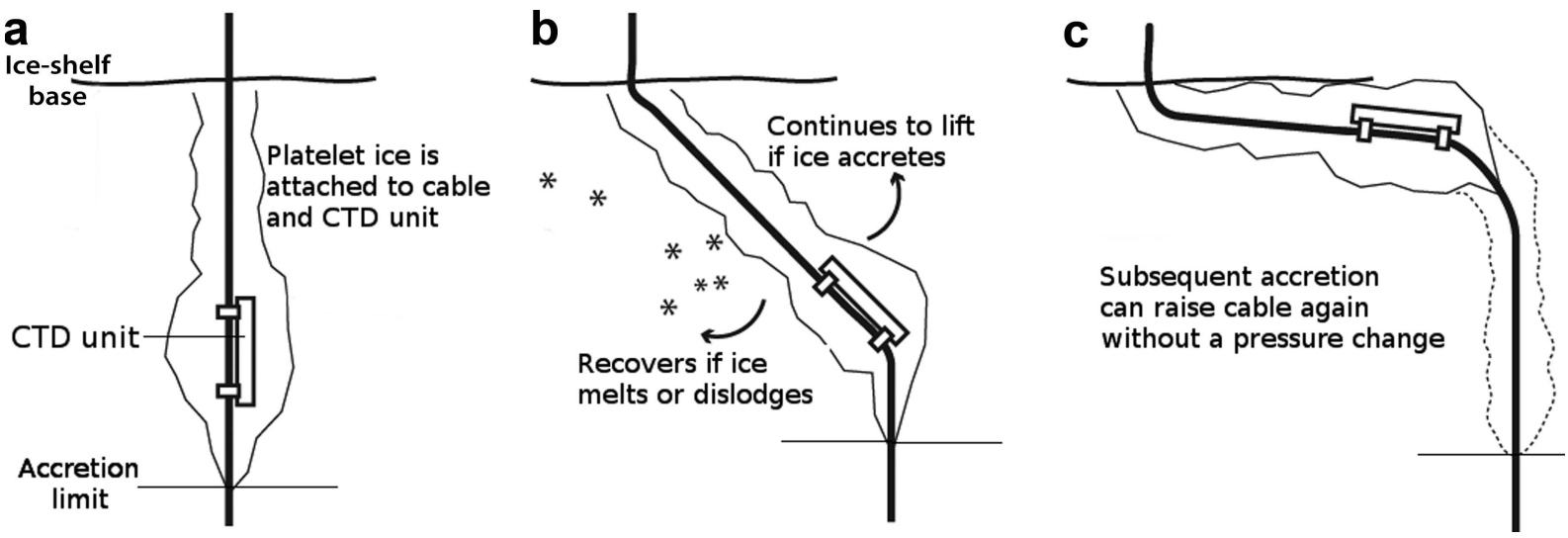

Fig. 5. Simple schematic (not to scale) of stages of ice accretion and associated motions of the upper part of a mooring.

100-200 hPa (1-2 dbar) are an order of magnitude smaller than our abrupt changes, occur over several days and are transient, associated with the passage of synoptic weather systems. Accordingly, they can be discounted as causing the major pressure events, particularly as the sudden jumps of 10-20 dbar that occur in the recovery phase of our transient events take place between half-hourly readings.

\section{Ocean currents}

Driven by ocean currents, small-amplitude transient pressure oscillations modulated at tidal frequencies are present in the mooring records from all six AMISOR sites. As the moorings are suspended from the ice shelf, such changes are generally smallest closer to the anchoring point, and largest for the deepest instrumentation on the mooring. As we discuss below, these tidal influences are not the primary cause of the abrupt pressure jumps, but apparently tidal modulations can be clearly seen at some sites during the abrupt transitions (e.g. Fig. 4c)

\section{Ice-shelf dynamics and changes in mass loading}

As the ice shelf flows seawards, ice deformation alters the ice thickness, typically by thinning it at steady strain rates of a fraction of a per cent per year. This is considered the major contributor to background pressure reductions of the order of $1-2 \mathrm{dbar}^{-1}$ at most AMISOR sites.

Changes in the mass loading of the ice shelf can be divided into two classes: regular changes in mass budget from snowfall and basal accretion, and infrequent major surface load changes at or near the sites. Impacts from snow accumulation events, even as large as $1 \mathrm{~m}$ w.e., are an order of magnitude too small and of the wrong sign (causing pressure increases). Basal accretion events of as much as $1 \mathrm{~m}$ w.e. only raise the ice shelf by about a tenth of that, and are two orders of magnitude too small. We accordingly discount these effects.

Rapid large-scale changes in regional ice-shelf mass loading could be caused by the drainage or redistribution of liquid water on the surface, or within large-scale crevassing. While extensive surface melting exists over the southern half of the Amery Ice Shelf (Fricker and others, 2002), no largescale surface water features, such as lakes 10-20 m deep, are known in the region of our observations. Hidden sources such as water-filled crevasses are a possibility, though no surface expression of these exists around the mooring sites. No abrupt surface-elevation changes of the order of our pressure changes were observed there, nor any unusual surface features indicative of large-scale crevassing. These would have been clearly visible from the air or ground during annual visits. Furthermore, even granting the possibility of rapid drainage of such hydraulic features (e.g. to produce dolines seen at the southern end of the ice shelf (Mellor and McKinnon, 1960)), it seems impossible to reconcile the requirement for their even more sudden replenishment within half an hour, during the recovery phase of transient events. This mechanism also would not explain why the events we observed were confined to the sites along the marine ice band.

\section{Ice accretion and mooring buoyancy}

The only remaining explanation of the abrupt pressure events is a change in buoyancy of the moorings themselves. As schematically depicted in Figure 5, frazil that has formed in the water column can attach and grow as platelets on the mooring cable and the upper CTD instrument (which is within $20 \mathrm{~m}$ of the ice-shelf base). Continued accretion can provide sufficient buoyancy to raise the mooring until the upper instrument and the ice 'float' is against the base of the ice shelf. The initial permanent displacements are consistent with the upper instrument rising to the ice-shelf base, making allowance for marine ice accretion rates. If the platelet shroud is not displaced by this motion, then the upper instrument can become frozen into the marine ice layer as it slowly consolidates over time. Direct observations from sea-ice studies confirm that platelet ice crystal attachments can generate enough buoyancy force to cause the lifting of mooring cables suspended in the water column (Hunt and others, 2003; Leonard and others, 2006).

The magnitudes of the recorded pressure changes during the events are identical on all active sensors until the first permanent lifting event. This indicates that platelet ice attachment is concentrated along the upper portion of the mooring, and that at this stage any ice accretion below the upper CTD is insufficient to provide the further buoyancy required to raise the remainder of the mooring by an additional amount. After the permanent pressure changes, the upper sensors at each site no longer register the abrupt events as they are at the ice-shelf base as discussed later.

The upper CTDs were deployed in the ocean boundary layer, near the base of the ice shelf, where temperatures close to or below the in situ freezing-point temperature occur, and frazil ice is likely to form or persist in the water column. The temperatures at the deeper sensors are typically higher than the in situ freezing point of sea water (by $0.1-0.4^{\circ} \mathrm{C}$ ), so ice 
growth cannot occur at those depths. We have limited information about the temporal evolution of the vertical structure of the water column at the moorings, in particular regarding the depth of the colder, fresher mixed layer at the ice-shelf base that typically surrounds the upper CTD units. CTD profiles were taken at each borehole before the moorings were installed. This always occurred during the austral summer. Craven and others (2004) reported that at AM01 the mixed layer was $80-100 \mathrm{~m}$ thick, with the top $\sim 50 \mathrm{~m}$ supercooled relative to the in situ freezing temperature. A cast from AM04 presented by Breitenmoser (2008) indicates the cold mixed layer extends $\sim 10 \mathrm{~m}$ below the upper mooring CTD. At AM05 the mixed layer thickness was 50-60 m (Rosenberg and others, unpublished ACE CRC internal report).

\section{Effects on upper temperature measurements}

All the major pressure events occur during periods when the mixed layer temperature from the upper CTD is at or below the in situ freezing temperature, providing an environment where frazil can be present and freezing can occur. Immediately preceding the events the variability in temperature decreases. Prior high variability may be indicative of turbulent flow and mixing as salts are rejected during the freezing process. If ice crystals slowly coat the mooring cable they can also encrust the upper CTD unit. As the ice cover grows, it slowly shields the instrumentation, which will dampen temperature (and salinity) fluctuations in the records. Assuming the ice casing is porous, the conditions inside will remain sensitive to pressure. As the ice accretion grows, buoyancy increases until a threshold is reached where it exceeds the weight of the mooring, which will then be raised towards the ice-shelf base until the balance of forces is restored. As the ice-encrusted upper CTD is lifted it measures temperature changes as the water inside the porous ice casing equilibrates to its new pressure environment.

\section{Abrupt increases in pressure}

There are several possible explanations for the abrupt pressure increases that terminate the major transient events seen in the pressure records (e.g. Figs $2 \mathrm{a}$ and c and $4 \mathrm{~b}$ ). Firstly, platelet crystals may be dislodged from the mooring (Fig. 5b), perhaps due to mechanical flexing of the cable as it bends, resulting in a loss of buoyancy, allowing the mooring to return to its original depth and vertical configuration. Secondly, for the more prolonged transient events lasting several days, loss of buoyancy could also be the result of crystal dislodgement during a period of higher current flow near the ice-shelf base. Lastly, relatively warm water intrusions could cause either direct melting of the platelets or enhanced dislodgement from the mooring by weakening any sintering bonds that have formed.

Both Leonard and others (2006) and Mahoney and others (2011) report periods of extensive platelet ice attachment associated with supercooling events in McMurdo Sound being interspersed with periods of reduced or no platelet ice attachment. This is consistent with the observations of transient buoyancy events reported here.

\section{Mooring attachment to the ice-shelf base}

Once sufficient platelet crystals are firmly attached the mooring is raised and, in the initial permanent events, the upper instrument appears to lodge within the marine ice layer at the base of the ice shelf. The deepest section of the marine ice layer is permeable and the platelet aggregation there only consolidates slowly over time (Craven and others, 2009), so the upper instrument on the mooring can be pressed against this basal layer by net buoyancy forces on the instrument and cable, and become embedded more permanently thereafter. Freeze-in of the upper CTD will remove this instrument from the dynamic system in the sub-ice-shelf mixed layer, so that evidence for subsequent abrupt pressure events only comes from the middle and bottom sensors (Fig. 2c and f). The recovery phases of transient events are always abrupt as the removal of a critical mass of crystals results in immediate loss of the net buoyancy force required for lift. We presume that this occurs before substantial load-bearing bonds are formed with the ice-shelf base.

The magnitude of the pressure change once the mooring becomes buoyant shows the distance the mooring is raised before the net buoyant force is obstructed, and therefore gives an indication of the minimum vertical extent of the region where ice is being accreted. In fact, at all three sites the magnitude of the major pressure changes is remarkably similar (Table 1). The depth of the upper instrument below the ice-shelf base is very nearly the same at all three sites, which suggests that the upper instrument itself may develop a larger ice 'float', which effectively controls the lift. The greater surface area of the instrument and its cable clamps may mean that more ice accretes there, compared with the mooring cable, enhancing the volume of the ice float at the depth of the upper CTD.

As an estimate of feasibility, an instrument string with a suspended weight (in air) of $\sim 90 \mathrm{~kg}$ (consisting of three $5 \mathrm{~kg}$ Seabird sensors, two $15 \mathrm{~kg}$ weights and $45 \mathrm{~kg}(300 \mathrm{~m})$ of cable) has an effective weight in sea water of $\sim 74 \mathrm{~kg}$, and would achieve neutral buoyancy if encased by a $20 \mathrm{~m}$ long cylinder of ice with a radius of $\sim 10 \mathrm{~cm}$ (for a sea-water density of $1027 \mathrm{~kg} \mathrm{~m}^{-3}$ and ice density of $917 \mathrm{~kg} \mathrm{~m}^{-3}$ ). Given that the crystals likely attach loosely at first, gradually consolidating, the actual diameter is probably larger. This fits well with observations of ice casings $30 \mathrm{~cm}$ in diameter observed on moorings beneath sea ice, whose characteristic shape is essentially cylindrical although tapering away with depth (Hunt and others, 2003; Leonard and others, 2006). Our conclusions are also compatible with observations of a $7 \mathrm{~m}$ uplift of a $70 \mathrm{~kg}$ mooring occurring over 5 days in late August beneath the sea-ice cover in McMurdo Sound (Mahoney and others, 2011).

At AM05 the pressure sensor in the upper instrument failed soon after deployment, but the $15 \mathrm{dbar}$ pressure reduction recorded by the deeper instruments shows that the concurrent temperature increase for the top CTD of $\sim 0.01^{\circ} \mathrm{C}$ is consistent with a change of in situ freezing temperature associated with a lift of $\sim 15 \mathrm{dbar}$ (Fig. 3b). Once again, this can be interpreted as the upper CTD being raised against the base of the ice shelf by the platelet ice accretion as the entire instrument string is raised $\sim 15 \mathrm{~m}$ in the water column. The small pressure drop $(\sim 2.5 \mathrm{dbar})$ in the middle and lower sensors at AM05 earlier that year, around DoY 100 (April), is preceded by $\sim 75$ days of water that is frequently in situ supercooled, suggesting either a period of prolonged formation of frazil in the water column, or a steady streaming of water bearing frazil through the site. The variability of the temperature is markedly reduced after that minor event (Fig. 3e), suggesting some ice accretion around the top CTD as discussed above. 
Under such a scenario (Fig. 5) we conclude that major accretion of platelet ice occurs on the upper section of the mooring to at least $15-20 \mathrm{~m}$ immediately beneath the iceshelf base, although frazil presence and production in the water column and accretion on the mooring may also occur at greater depths. Indeed, contemplating such large vertical displacements, it is natural to speculate about ice accretion well below the 'ice float' forming around the CTD. Accretion proceeds until sufficient ice accumulates to provide the necessary buoyancy force to raise the entire mooring, a process that continually brings new cable sections into the accretion zone.

The degree and depth of in situ supercooling controls the ice accretion zone. The uniform temperature mixed layer may continue for some distance below the upper CTDs. In this situation, the degree of in situ supercooling (when present) at those instruments, typically in the range $0.01-0.02^{\circ} \mathrm{C}$ at AM04 and AM05 (Figs $2 \mathrm{~d}$ and e and $3 \mathrm{c}$ ), suggests a zone below those CTDs, where frazil can exist and platelet ice accrete on moorings. Given a uniform mixed layer temperature, this zone would taper off about 20-25 m below the upper CTD, giving a total thickness for ice persistence, growth and accretion of $\sim 40 \mathrm{~m}$.

\section{Tidal modulations}

Moorings in the ocean cavity are subject to forcing by tidal currents, combined with any background flows. These effects are amplified as the mooring string approaches a state of neutral buoyancy, and as the accreted ice increases the drag forces. Tidal current strengths may also influence the rate at which ice attaches to the mooring. Tidal flexing of the mooring cable could also potentially contribute to shedding of platelets, thus delaying the eventual raising of the upper instrument against the base of the shelf.

What appear to be larger than usual tidally modulated pressure oscillations are clearly evident immediately prior to the large pressure drops at AM04 in 2008 and 2009, and during the pressure jumps at AM01. There are clear variations in pressure for all three sensors at AM04 (Fig. 2a and $b$ ). The amplitude of the pressure variations from the uppermost CTD also becomes markedly larger in the leadup to the major pressure drops. In 2003 the initial pressure drop at AM01 in early April, DoY 95 (Fig. 4c and f), showed an apparent tidal signal superimposed on the transition that occurred over $\sim 3$ days.

\section{INFERENCES ABOUT SUB-ICE-SHELF OCEAN PROCESSES}

The scientific value of our observations is that they provide indirect evidence for the presence of frazil in the water column in environmental conditions which allow platelet ice attachment leading to active marine ice accretion at the base of the Amery Ice Shelf. These events are also a cautionary tale for experimental design when deploying moorings into in situ supercooled waters.

A quick review of the observations reveals seasonal changes in water masses in the mixed layer near the iceshelf base at AM04 and AM01 (Figs 2d and e and 4d and e). At both locations the ice attachment process appears to be an annual event, which is ended by the arrival of warmer water masses at the beginning of the austral spring. Due to the scarcity of observations it is difficult to infer much from their apparent relative timing at the sites. However, notwithstanding interannual variability, the northernmost site AM01 does appear to produce events earlier in the year (February-June) than the AM04 upstream site (June-August). This may well be a reflection of circulation patterns in the ice-shelf cavity, which determine whether local freezing or melting can occur, and indeed modelling shows that a frazilladen ice-shelf water plume is diverted to flow past AM01 (at about DoY 100) as much as 100 days earlier than at AM04 (Galton-Fenzi and others, 2012; Post and others, 2014). Our observations also indicate (Fig. 3c) that AM05 may be subject to a different regime in which freezing conditions can occur throughout the year.

At AM01, the two major transients followed by a sustained pressure drop (Fig. $4 \mathrm{~b}$ and e) allow an inference of initial (porous) marine ice accretion rates. The magnitudes of the events, in sequence, are 19.0, 18.5 and $17.5 \mathrm{dbar}$, a difference of $1.5 \mathrm{dbar}$, over a 50 day period (Table 1). A conclusion that might be drawn from this sequence is that a dense layer of uncompacted platelet ice, up to $1.5 \mathrm{~m}$ thick, may have collected at the base of the ice shelf during this interval, which prevented the mooring from reaching the more consolidated ice above. Annual average consolidated marine ice layer growth between AM04 and AM01 has been estimated at $\sim 1$ m ice eq. $\mathrm{a}^{-1}$ (Craven and others, 2009).

In 2009 at AM04 the background trend of declining pressure became stronger for all three instruments after the sustained pressure drop (Fig. 2b). Assuming the initial trend in 2008 (Fig. 2a) and 2009 (prior to the jump) was due to strain thinning of the ice shelf, the higher rate afterwards may be due to an additional contribution from buoyancydriven compaction of ice crystals at the base of the ice shelf. This may indicate that after the initial lift (in 2009) the upper CTD, now firmly entrained in the developing marine ice layer, hauls the deeper instruments up as compaction occurs. As the marine ice layer forms there, the new anchor point of the mooring is rising as this band of platelet ice is compressed. The difference in the rates amounts to the equivalent of another $\sim 1 \mathrm{~cm} \mathrm{~d}^{-1}$ at the site. A similar effect is seen for the deeper sensors at AM05 after the 2011 sustained pressure drop (Fig. 3b). For AM01 the increased rate has a delayed response of $\sim 40$ days (Fig. 4 b) but then experiences a similar faster background pressure reduction trend. The three sites together suggest a consistent initial compaction rate of $3-4 \mathrm{~m} \mathrm{a}^{-1}$ for this incipient frazil-slush-plateletmarine-ice layer.

At AM04 in 2010 the background pressure at the upper sensor continues to decline at the higher rate established after the 2009 jump, even after the large pressure event recorded by the lower sensors following DoY 227 (Fig. 2c); however, the deeper sensors show no pressure trend following the end of that event at DoY 270. Since this major lift in 2010 only involves buoyancy from ice accreting on the mooring cable, it may not provide a robust new anchor point within the basal platelet layer. Without the nucleus of a CTD unit, the connection is potentially subject to minor detachments and buoyancy losses, thus decoupling the deeper sensors from the top sensor, at least for the remainder of the short record.

The potential for attachment of ice shrouds to mooring strings and instruments suspended beneath ice shelves, floating glacier tongues and sea-ice cover where there is in situ supercooled water, frazil, platelet or marine ice growth, has important ramifications for projects and instrumentation designed to investigate ice/ocean interactions and processes. 
The boundary layer at the ice/water interface is of particular interest. Recent advances in technology have seen the development of ice-tethered profilers (Krishfield and others, 2008) and the adoption of fibre-optic cables for distributed temperature sensing on moorings (Warner and others, 2012; Tyler and others, 2013). Ice-tethered profilers have a parking depth between profiles that should take into account bending and lifting of the tether as well as fouling of onboard sensors. Fibre-optic cables could experience considerable bending that might influence the optical transmission properties of the fibre, potentially even providing evidence of such events. Acoustic Doppler current profilers suspended $>100 \mathrm{~m}$ beneath the ice base can potentially detect patches of frazil in the water column, and may take longer to be elevated within the range where actual platelet ice attachment occurs, but could also suffer severe signal loss from dense frazil clouds forming above or around them. However, a phenomenon that may initially hinder observations can also potentially provide unique opportunities to study the process itself, especially given prior knowledge of its potential occurrence.

\section{CONCLUSIONS}

We have shown that instrument strings moored in the ocean cavity beneath the Amery Ice Shelf underwent characteristic abrupt pressure changes at sites where a marine ice layer is present at the base of the shelf and basal ice accretion is believed to occur. These transitions occurred over periods of a few days and are attributed to the attachment of platelet ice crystals on the upper part of the moorings to such an extent that buoyancy is achieved and the mooring strings are raised against the underside of the ice shelf. Temperature changes in the upper sensors match changes of in situ seawater freezing temperatures expected for the associated decrease in pressure.

We infer from our observations that active marine ice accretion occurs at each of these three field sites. Estimated long-term basal marine ice accretion rates for these sites are 1-2 $\mathrm{m} \mathrm{a}^{-1}$ (Craven and others, 2009), and at AM01 we infer a similar rate from a succession of abrupt pressure variations. Initial review of the temperature data for the two northernmost sites indicates an annual cycle in which warmer water masses arriving in austral spring end a prolonged period of frazil production and marine ice accretion. The magnitude of the pressure changes, and the evidence for supercooled water from the temperature data, suggest that the minimum extent of the layer of frazil bearing water near the ice-shelf base is at least $10-20 \mathrm{~m}$ thick.

Aside from their scientific importance, our observations underline the potential for ice to attach to moorings, causing significant vertical displacement of instrument deployments. This has ramifications both for the future mooring of instrumentation at sites with active marine ice accretion, and for the interpretation of sub-ice ocean data collected there. This is important because interactions and processes close to the ice/water interface are crucial for understanding the evolution and long-term stability of ice shelves.

\section{ACKNOWLEDGEMENTS}

We acknowledge logistic support from the Australian Antarctic Division and invaluable input from the hot-water drill teams and the many people who contributed to the AMISOR
ASAC (Australian Antarctic Science Advisory Council) 1164 field program. This work was supported by the Australian Government's Cooperative Research Centres Program through the Antarctic Climate and Ecosystems CRC. We acknowledge insightful remarks from Keith Makinson and an anonymous reviewer, and thank the scientific editor, Helen Fricker, for helpful suggestions that improved the structure and clarity of the paper.

\section{REFERENCES}

Barry JP (1988) Hydrographic patterns in McMurdo Sound, Antarctica and their relationship to local benthic communities. Polar Biol., 8(5), 377-391 (doi: 10.1007/BF00442029)

Breitenmoser P (2008) Pattern of water property changes beneath the Amery Ice Shelf and possible causes. (Honours thesis, University of Tasmania)

Craven $M$ and 6 others (2004) Initial borehole results from the Amery Ice Shelf hot-water drilling project. Ann. Glaciol., 39, 531-539 (doi: 10.3189/172756404781814311)

Craven $\mathrm{M}$ and 7 others (2005) Borehole imagery of meteoric and marine ice layers in the Amery Ice Shelf, East Antarctica. J. Glaciol., 51(172), 75-84 (doi: 10.3189/172756505781829511)

Craven M, Allison I, Fricker HA and Warner R (2009) Properties of a marine ice layer under the Amery Ice Shelf, East Antarctica. J. Glaciol., 55(192), 717-728 (doi: 10.3189/ 002214309789470941)

Depoorter MA and 6 others (2013) Calving fluxes and basal melt rates of Antarctic ice shelves. Nature, 502(7469), 89-92 (doi: 10.1038/nature12567)

Dupont TK and Alley RB (2005) Assessment of the importance of ice-shelf buttressing to ice-sheet flow. Geophys. Res. Lett., 32(4), L04503 (doi: 10.1029/2004GL022024)

Foldvik A and Kvinge T (1974) Conditional instability of sea water at the freezing point. Deep-Sea Res., 21(3), 169-174 (doi: 10.1016/0011-7471(74)90056-4)

Fricker HA, Popov S, Allison I and Young N (2001) Distribution of marine ice beneath the Amery Ice Shelf. Geophys. Res. Lett., 28(11), 2241-2244 (doi: 10.1029/2000GL012461)

Fricker HA and 9 others (2002) Redefinition of the Amery Ice Shelf, East Antarctica, grounding zone. J. Geophys. Res., 107(B5), 2092 (doi: 10.1029/2001JB000383)

Galton-Fenzi BK, Maraldi C, Coleman R and Hunter J (2008) The cavity under the Amery Ice Shelf, East Antarctica. J. Glaciol., 54(188), 881-887 (doi: 10.3189/002214308787779898)

Galton-Fenzi BK, Hunter JR, Coleman J, Marsland SJ and Warner RC (2012) Modeling the basal melting and marine ice accretion of the Amery Ice Shelf. J. Geophys. Res., 117(C9), C09031 (doi: 10.1029/2012JC008214)

Gough AJ, Mahoney AR, Langhorne PJ, Williams MJM, Robinson NJ and Haskell TG (2012) Signatures of supercooling: McMurdo Sound platelet ice. J. Glaciol., 58(207), 38-50 (doi: 10.3189/ 2012JoG10J218)

Gudmundsson GH (2013) Ice-shelf buttressing and the stability of marine ice sheets. Cryosphere, 7(2), 647-655 (doi: 10.5194/tc7-647-2013)

Hubbard B, Tison J-L, Pattyn F, Dierckx M, Boereboom T and Samyn D (2012) Optical-televiewer-based identification and characterization of material facies associated with an Antarctic ice-shelf rift. Ann. Glaciol., 53(60 Pt 2), 137-146 (doi: 10.3189/ 2012AoG60A045)

Hulbe CL, Johnston R, Joughin I and Scambos T (2005) Marine ice modification of fringing ice shelf flow. Arct. Antarct. Alp. Res., 37(3), 323-330 (doi: 10.1657/1523-0430(2005)037[0323 MIMOFI]2.0.CO;2)

Hunt BM, Hoefling K and Cheng CC (2003) Annual warming episodes in seawater temperatures in McMurdo Sound in relationship to endogenous ice in notothenioid fish. Antarct. Sci., 15(3), 333-338 (doi: 10.1017/S0954102003001342) 
Jacobs SS, Hellmer HH, Doake CSM, Jenkins A and Frolich RM (1992) Melting of ice shelves and the mass balance of Antarctica. J. Glaciol., 38(130), 375-387

Krishfield R, Toole J, Proshutinsky A and Timmermans M-L (2008) Automated ice-tethered profilers for seawater observations under pack ice in all seasons. J. Atmos. Ocean. Technol., 25(11), 2091-2105 (doi: 10.1175/2008JTECHO587.1)

Lambrecht A, Sandhager H, Vaughan DG and Mayer C (2007) New ice thickness maps of Filchner-Ronne Ice Shelf, Antarctica, with specific focus on grounding lines and marine ice. Antarct. Sci., 19(4), 521-532 (doi: 10.1017/S0954102007000661)

Lange MA (1988) Basic properties of Antarctic sea ice as revealed by textural analysis of ice cores. Ann. Glaciol., 10, 95-101

Lange MA and MacAyeal DR (1986) Numerical models of the Filchner-Ronne Ice Shelf: an assessment of reinterpreted ice thickness distributions. J. Geophys. Res., 91(B10), 10 457-10 462 (doi: 10.1029/JB091iB10p10457)

Leffanue $\mathrm{H}$ and Craven M (2004) Circulation and water masses from current meter and T/S measurements at the Amery Ice Shelf. In Smedsrud LH ed. FRISP Rep. 15, 73-79

Leonard GH, Purdie CR, Langhorne PJ, Haskell TG, Williams MJM and Frew RD (2006) Observations of platelet ice growth and oceanographic conditions during the winter of 2003 in McMurdo Sound, Antarctica. J. Geophys. Res., 111(C4), C04012 (doi: 10.1029/2005JC002952)

Leonard GH and 7 others (2011) Evolution of supercooling under coastal Antarctic sea ice during winter. Antarct. Sci., 23(4), 399-409 (doi: 10.1017/S0954102011000265)

Lewis EL and Perkin RG (1986) Ice pumps and their rates. J. Geophys. Res., 91(C10), 11756-11762 (doi: 10.1029/ JC091iC10p11756)

McDougall TJ and Barker PM (2011) Getting started with TEOS-10 and the Gibbs Seawater (GSW) Oceanographic Toolbox. SCOR/ IAPSO WG127 http://www.teos-10.org/software.htm

Mahoney AR and 6 others (2011) The seasonal appearance of ice shelf water in coastal Antarctica and its effect on sea ice growth. J. Geophys. Res., 116(C11), C11032 (doi: 10.1029/ 2011JC007060)

Mellor M and McKinnon G (1960) The Amery Ice Shelf and its hinterland. Polar Rec., 10(64), 30-34 (doi: 10.1017/ S0032247400050579)

Morgan VI (1972) Oxygen isotope evidence for bottom freezing on the Amery Ice Shelf. Nature, 238(5364), 393-394 (doi: 10.1038/ 238393a0)

Nicholls KW and Jenkins A (1993) Temperature and salinity beneath Ronne Ice Shelf, Antarctica. J. Geophys. Res., 98(C12), 22 553-22 568 (doi: 10.1029/93JC02601)

Oerter $\mathrm{H}$ and 6 others (1992) Evidence for basal marine ice in the Filchner-Ronne Ice Shelf. Nature, 358(6385), 399-401 (doi: 10.1038/358399a0)

Penrose JD, Conde M and Pauly TJ (1994) Acoustic detection of ice crystals in Antarctic waters. J. Geophys. Res., 99(C6), 12 573-12 580 (doi: 10.1029/93JC03507)

Post AL and 8 others (2014) Modern sedimentation, circulation and life beneath the Amery Ice Shelf, East Antarctica. Continental Shelf Res., 74, 77-87 (doi: 10.1016/j.csr.2013.10.010)

Pritchard HD, Ligtenberg SRM, Fricker HA, Vaughan DG, Van den Broeke MR and Padman L (2012) Antarctic ice-sheet loss driven by basal melting of ice shelves. Nature, 484(7395), 502-505 (doi: 10.1038/nature10968)

Rignot E and Jacobs SS (2002) Rapid bottom melting widespread near Antarctic ice sheet grounding lines. Science, 296(5575), 2020-2023 (doi: 10.1126/science.1070942)

Rignot E, Casassa G, Gogineni P, Krabill W, Rivera A and Thomas R (2004) Accelerated ice discharge from the Antarctic Peninsula following the collapse of Larsen B ice shelf. Geophys. Res. Lett., 31(18), L18401 (doi: 10.1029/2004GL020697)

Rignot E, Mouginot J and Scheuchl B (2011) Ice flow of the Antarctic Ice Sheet. Science, 333(6048), 1427-1430 (doi: 10.1126/science.1208336)

Rignot E, Jacobs S, Mouginot J and Scheuchl B (2013) Ice shelf melting around Antarctica. Science, 341(6143), 266-270 (doi: 10.1126/science.1235798)

Rott H, Rack W, Skvarca P and De Angelis H (2002) Northern Larsen Ice Shelf, Antarctica: further retreat after collapse. Ann. Glaciol., 34, 277-282 (doi: 10.3189/172756402781817716)

Scambos TA, Bohlander JA, Shuman CA and Skvarca P (2004) Glacier acceleration and thinning after ice shelf collapse in the Larsen B embayment, Antarctica. Geophys. Res. Lett., 31(18), L18402 (doi: 10.1029/2004GL020670)

Shepherd A, Wingham D and Rignot E (2004) Warm ocean is eroding West Antarctic Ice Sheet. Geophys. Res. Lett., 31(23), L23402 (doi: 10.1029/2004GL021106)

Smith IJ, Langhorne PJ, Haskell TG, Trodahl HJ, Frew R and Vennell MR (2001) Platelet ice and the land-fast sea ice of McMurdo Sound, Antarctica. Ann. Glaciol., 33, 21-27 (doi: 10.3189/ 172756401781818365)

Thomas RH and MacAyeal DR (1982) Derived characteristics of the Ross Ice Shelf, Antarctica. J. Glaciol., 28(100), 397-412

Thyssen F (1988) Special aspects of the central part of FilchnerRonne Ice Shelf, Antarctica. Ann. Glaciol., 11, 173-179

Tison J-L, Lorrain RD, Bouzette A, Dini $M$, Bondesan A and Stiévenard M (1998) Linking landfast sea ice variability to marine ice accretion at Hells Gate Ice Shelf, Ross Sea. In Jeffries $\mathrm{MO}$ ed. Antarctic sea ice: physical processes, interactions and variability. (Antarctic Research Series 74) American Geophysical Union, Washington, DC, 375-407

Treverrow A, Warner RC, Budd WF and Craven M (2010) Meteoric and marine ice crystal orientation fabrics from the Amery Ice Shelf, East Antarctica. J. Glaciol., 56(199), 877-890 (doi: 10.3189/002214310794457353)

Tyler SW and 8 others (2013) Using distributed temperature sensors to monitor an Antarctic ice shelf and sub-ice-shelf cavity. J. Glaciol., 59(215), 583-591 (doi: 10.3189/2013JoG12J207)

Warner R, Craven M, Galton-Fenzi B, Elcheikh A, Christensen A and Vogel SW (2012) Distributed temperature sensing in the Amery Ice shelf and the sub ice shelf ocean. In Hancke $M$ and Kirchner $\mathrm{N}$ eds. Proceedings of 26th International Forum for Research into Ice Shelf Processes (FRISP), 12-14 June 2012, Stockholm Archipelago, Sweden. Stockholm University for the FRISP Network, Stockholm

Wright CS and Priestley RE (1922) British (Terra Nova) Antarctic Expedition 1910-13. Glaciology. Harrison and Sons, London

Zotikov IA, Zagorodnov VS and Raikovsky JV (1980) Core drilling through the Ross Ice Shelf (Antarctica) confirmed basal freezing. Science, 207(4438), 1463-1465 (doi: 10.1126/science.207. 4438.1463) 